\title{
Vegetation Composition and Biomass Production in Community Forest in Sikre VDC adjoining Shivapuri National Park, Kathmandu
}

\author{
Sudip Pandey ${ }^{1}$ and Siddhartha Bajra Bajracharya ${ }^{2}$ \\ ${ }^{1}$ Nepal Academy of Science and Technology, Khumaltar, Lalitpur \\ ${ }^{2}$ National Trust for Nature Conservation, Khumaltar, Lalitpur \\ e-mail:environ.sudip@gmail.com
}

\begin{abstract}
The present study describes the structural and floral composition of the vegetation of Sikre Village Development Committee (VDC) at Shivapuri National Park. Systematic sampling technique was used to analyze the vegetation of the forest. A quadrat size of $10 \mathrm{mx} 10 \mathrm{~m}$ was plotted at respective point for tree study and within $5 \mathrm{mx} 5 \mathrm{~m}$ plots for shrubs and $1 \mathrm{mx} 1 \mathrm{~m}$ for herbs analysis. The study recorded a total of 18 tree species from 13 families in the forest area. Among the trees, Uttis (Alnus nepalensis D. Don) and Chilaune [Schima wallichii (DC.) Korth.] were the most dominant species. The major shrubs of the forest areas comprised of Yurilo (Hypericum uralum Buch.-Ham. ex D. Don), Chutro (Berberis aristata DC.) and Angeri (Melastoma melabathricum L.). Among the herbs Bhui Amala (Phyllanthus freternus Webster), Unyu [Dryopteris filix-mas (L.) Schott.] and Banmara (Eupatorium adenophorum Spreng.) were dominant ones in forest ground. The aboveground biomass of tree species was found to be $4021.41 \mathrm{~kg} / \mathrm{ha}$ in which Dhalne katus [Castanopsis indica (Roxb.) Miq.] constituted the large percent of biomass of the forest. The estimated resources demand and supply showed the annual deficit of 112.038t/yr and the carbon stock was calculated to be 2.01t/ha. The Shannon Index of diversity was highest for tree (2.33) followed by shrub (2.22) and herb (2.17) respectively. The density of cut stumps and the density of lopping were 184/ha and 216/ha respectively, which showed that the anthropogenic pressure on community forest was prominent.
\end{abstract}

Key words: basal area, biomass, species diversity, systematic sampling

\section{Introduction}

Human impact has, to varying degree, led to a reduction in biodiversity in much of the forest areas of Nepal (Chaudhary \& Kunwar 2002, Karki 1991). Conservation of such forests requires an understanding of the composition of the particular forest, the effects of past disturbances, and the present impact of neighboring land use on that forest (Geldenhuys \& Murray 1993). In order to understand the phyto-sociological structure of the Himalayan forests, we need studies that deal with the distribution of individual plant species of various girth classes, association among species, pattern of dispersion and various indices of diversity (Longman \& Jenik 1987).
Community forest (CF) appears to have stood the test of time, contributing to the welfare of the mass of rural poor in Nepal. By April 2009, about 1.6 million households or one-third of the country's population took part in the CF program, directly managing more than $1,000,000$ ha or more than one-fourth of the country's forest area. Therefore, it is expected that community forestry will act as a focal point for village development, environmental stability and contribute to sustainable development of nation itself (Ojha \& Pokharel 2005).

The objectives of this study were to determine the status of forests, sustainable demand and supply of 
resources and diversity components of vegetation in community forests of Sikre VDC, Nuwakot, Nepal.

\section{Methodology}

\section{Site description}

Sikre VDC with an area of $15.31 \mathrm{~km}^{2}\left(27^{\circ} 45^{\prime}\right.$ to $27^{\circ} 51^{\prime} \mathrm{N}$ and $85^{\circ} 21^{\prime}$ to $85^{\circ} 23^{\prime} \mathrm{E}$ ) is situated on the northern fringe of Shivapuri National Park (ShNP) (Fig. 1). The elevation varies from $831 \mathrm{~m}$ to $2426 \mathrm{~m}$ above the sea level. There were six community forests in Sikre managed by Community Forest User Group (CFUG) covering an area of 39.8 ha. These forests are comprised of upper mixed hardwood with lower mixed hardwood forest, chir pine forest and oak forest (Amatya 1993). Major species were Schima wallichii, Castanopsis indica, Alnus nepalensis, Rhododendron arboreum, Pinus roxburghii, Quercus sp. Some of the wildlife found in the forest were common leopard (Panthera pardus), langur (Semnopithecus entellus), rhesus monkey (Macaca mulatta) and jungle cat (Felis chaus). The average maximum temperature reaches up to $19.75^{\circ} \mathrm{C}$ in summer and the average minimum temperature in winter reaches up to $10.02^{\circ} \mathrm{C}$. The maximum rainfall $(691.70 \mathrm{~mm}$ ) occurs in July and the amount of rainfall decreases considerably in winter.
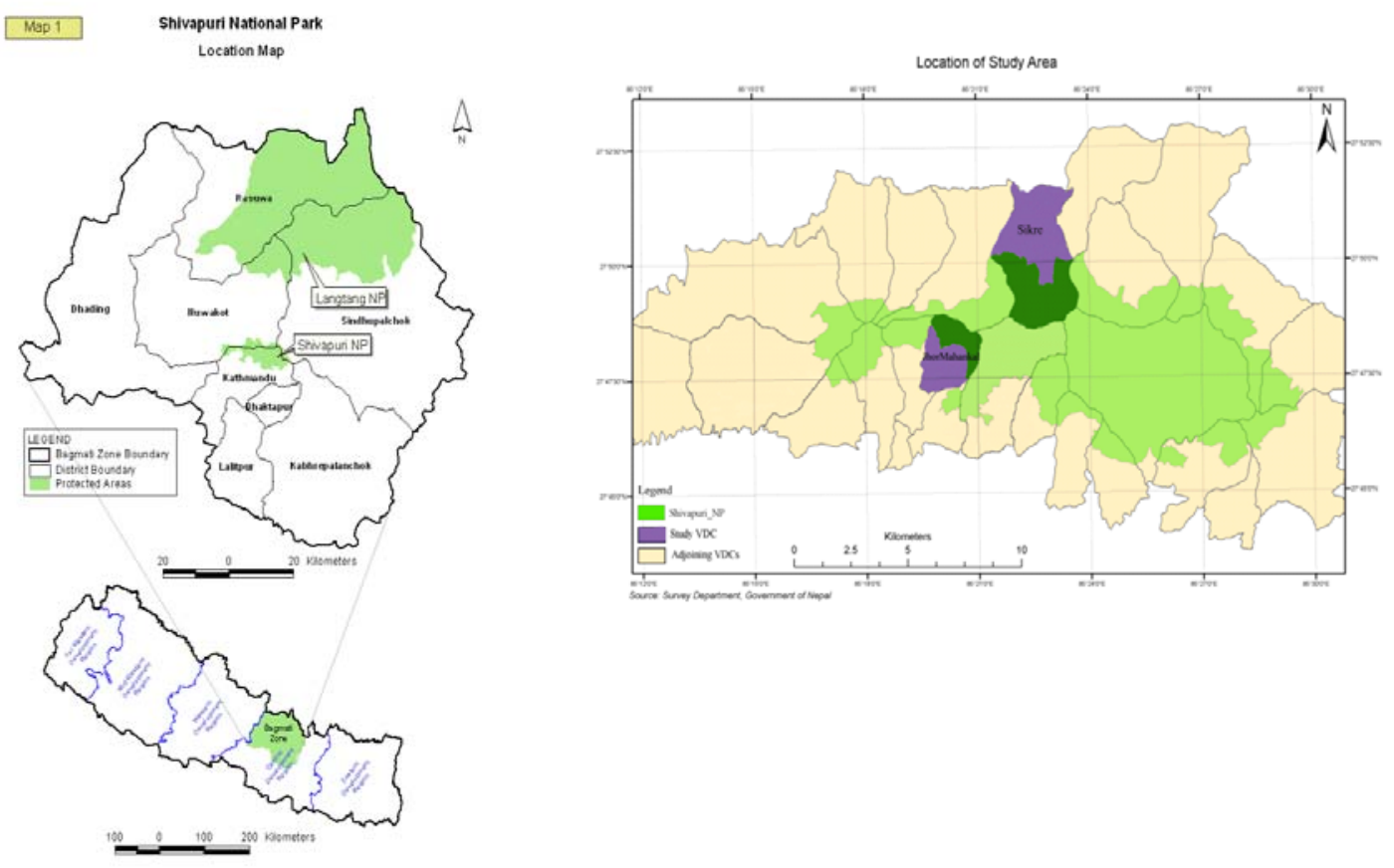

Fig. 1. Map showing the study area

\section{Method of study}

A field study was executed in community forests of Sikre VDC during the period of October to November 2008. We used systematic sampling with intensity of $0.5 \%$ to analyze the vegetation of the forest. The distance from first plot to the next was fixed according to the area of block of community forest and size of the sample plot. At each sampling point, altogether 10 plots were laid out.

Altogether 25 sampling plots of $10 \mathrm{mx} 10 \mathrm{~m}$ for trees, 50 sampling plots of $5 \mathrm{mx} 5 \mathrm{~m}$ for shrubs and 125 sampling plots of $1 \mathrm{mx} 1 \mathrm{~m}$ for herbs were plotted at respective point of study. In the places where the plots could not 
be made, the tree species were counted and quantitative analysis was carried out.

All tree species that fell within $10 \mathrm{mx} 10 \mathrm{~m}$ plot and having a diameter at breast height (dbh) greater than $10 \mathrm{~cm}$ were taken into account. Height and dbh of all trees were measured with the help of clinometer and dbh tape respectively. Sapling (greater than $1 \mathrm{~m}$ height and having dbh less than $10 \mathrm{~cm}$ ) and seedling (height $30 \mathrm{~cm}$ to $1 \mathrm{~m}$ ) were counted in sub-plots of $5 \mathrm{mx} 5 \mathrm{~m}$ and $5 \mathrm{mx} 2 \mathrm{~m}$ respectively inside sampling plots.

Number of cut stumps of tree species with height and circumference at top and lopping percent of tree species were noted in $10 \mathrm{mx} 10 \mathrm{~m}$ plots to quantify human interference, grazing pressure and management practice. Data were analyzed to calculate density and relative density; frequency and relative frequency; dominance and relative dominance following Kapur and Govil (2000). Importance Value Index (IVI) was calculated as the sum of relative basal area, relative density and relative frequency for trees whereas in case of shrub and herbs relative dominance and relative coverage were used respectively instead relative basal area.

For estimation of above ground biomass, a nondestructive method was used. The oven dry biomass of the tree components was calculated by using following biomass equation (NARMSAP \& DoF 2000).

$$
\operatorname{Ln}(\mathrm{W})=\mathrm{a}+\mathrm{bLn}(\mathrm{d})
$$

Where, $\mathrm{W}$ is above ground oven dry biomass of tree (kg), d is diameter at breast height (cm), and a, b are parameters estimated (NARMSAP \& DoF 2000).

Shannon-Wiener's Index (Shannon \& Weaver 1949) was calculated to measure species diversity. The Shannonwiener's index is;

$$
\mathrm{H}=-\Sigma \mathrm{p}_{\mathrm{i}} \operatorname{Ln} \mathrm{p}_{\mathrm{i}}
$$

Where, $\mathrm{H}$ is the index number, $\mathrm{s}$ is the total number of species, $\mathrm{p}_{\mathrm{i}}$ is the proportion of all individuals in the sample which belongs to species $\mathrm{i}$, and $\mathrm{Ln}$ is the natural $\log$, 2.718 .

Specimens of all species were collected and the herbarium was prepared for identification. Some of the plants were identified using standard reference (Stainton 1988, Shrestha 1998) and others with the help of specimens deposited at TUCH.

\section{Results Vegetation composition}

The study area contained natural as well as planted forest. It has a mixture of tall and medium height trees with a thick understorey of tangled shrubs and herbs, the composition varying according to soil and availability of water. The forest was dominated by Alnus nepalensis, Pinus roxburghii and Schima wallichii. Alnus nepalensis constituted $26.34 \%$ of the importance value (Table 1). Other important associated species were Albizia julibrissin, Castanopsis indica, Eurya accuminata, Myrica esculenta, Lyonia ovalifolia, etc. The understorey vegetation was composed of Hypericum uralum, Berberis aristata, Melastoma melabathricum. The ground vegetation was mainly represented by Capillipedium assimile, Eupatorium adenophorum and Biden pilosa.

\section{Density and basal area}

In the study area 18 tree species from 13 families were found. The total tree density was 840 stems/ha for tree and 2800 stems/ha for shrub. Similarly the total basal area was $689.23 \mathrm{~m}^{2} /$ ha (Table 1 ). The density of different species ranged from 4 to 196 stems/ha and basal area between 0.70 to $266.15 \mathrm{~m}^{2} / \mathrm{ha}$. A. nepalensis shared the highest density and higher basal area. The density of ground vegetation was found to be 669280 individuals/ha. The height classes of tree showed $46.60 \%$ of trees with height of less than $10 \mathrm{~m}$ and there were no trees with height class greater than $31 \mathrm{~m}$ (Fig. $3)$. The stand size classification showed high percent of poles (40.95\%) and sapling of 38.09\% (Fig. 2). These results showed that most of the stands are at intermediate stages of growth.

\section{Biomass}

The total living above ground biomass of trees was $4021.41 \mathrm{~kg} / \mathrm{ha}$ (Table 2). The highest above ground biomass in forest was contributed by $C$. indica (2190.7kg/ha) followed by M. esculenta (638.9kg/ha), and S. wallichii (229.79kg/ha). The carbon content of the forest can be calculated by multiplying the 0.5 conversion factors to above ground biomass (Brown et al. 1989). The mean carbon content of above ground biomass of the study area was found to be $2.01 \mathrm{t} / \mathrm{ha}$ which is lower than that in Champadevi community forest of Kirtipur (24.72tC/ha) as revealed by the study conducted by Khanal (2007). 
Table 1. Important value index of tree species

\begin{tabular}{|c|c|c|c|c|c|c|c|}
\hline Tree species & D/ha & $\begin{array}{l}\text { RD } \\
(\%)\end{array}$ & $\begin{array}{l}\text { F } \\
(\%)\end{array}$ & $\begin{array}{l}\text { RF } \\
(\%)\end{array}$ & $\begin{array}{l}\text { BA } \\
\text { (m²/ha) }\end{array}$ & RBA & IVI \\
\hline Albizia julibrissin & 8 & 0.95 & 8 & 2.43 & 7.02 & 1.01 & 4.41 \\
\hline Alnus nepalensis & 196 & 23.33 & 56 & 17.07 & 266.15 & 38.61 & 79.02 \\
\hline Castanopsis indica & 48 & 5.71 & 16 & 4.87 & 24.45 & 3.54 & 14.14 \\
\hline Choerospondias axillaris & 8 & 0.95 & 4 & 1.21 & 10.75 & 1.56 & 3.73 \\
\hline Engelhardia spicata & 12 & 1.42 & 8 & 2.43 & 13.51 & 1.96 & 5.82 \\
\hline Eurya accuminata & 36 & 4.28 & 24 & 7.31 & 5.09 & 0.73 & 12.34 \\
\hline Ficus semicordata & 4 & 0.47 & 4 & 1.21 & 2.27 & 0.32 & 2.02 \\
\hline Luculia grantissima & 8 & 0.95 & 8 & 2.43 & 0.70 & 0.10 & 3.49 \\
\hline Lyonia ovalifolia & 28 & 3.33 & 8 & 2.43 & 6.16 & 0.89 & 6.66 \\
\hline Maesa chisia & 32 & 3.80 & 8 & 2.43 & 6.86 & 0.99 & 7.24 \\
\hline Myrica esculenta & 64 & 7.61 & 24 & 7.31 & 39.81 & 5.77 & 20.71 \\
\hline Pinus roxburghii & 136 & 16.19 & 52 & 15.85 & 153.20 & 22.22 & 54.27 \\
\hline Pinus wallichiana & 48 & 5.71 & 8 & 2.43 & 19.19 & 2.78 & 10.93 \\
\hline Prunus cerasoides & 16 & 1.90 & 12 & 3.65 & 3.66 & 0.53 & 6.09 \\
\hline Pyrus pashia & 8 & 0.95 & 8 & 2.43 & 2.15 & 0.31 & 3.70 \\
\hline
\end{tabular}

D - Density, RD - Relative Density, F - Frequency, RF - Relative Frequency, BA - Basal Area, RBA - Relative Basal Area, IVI - Important Value Index, ha - Hectare
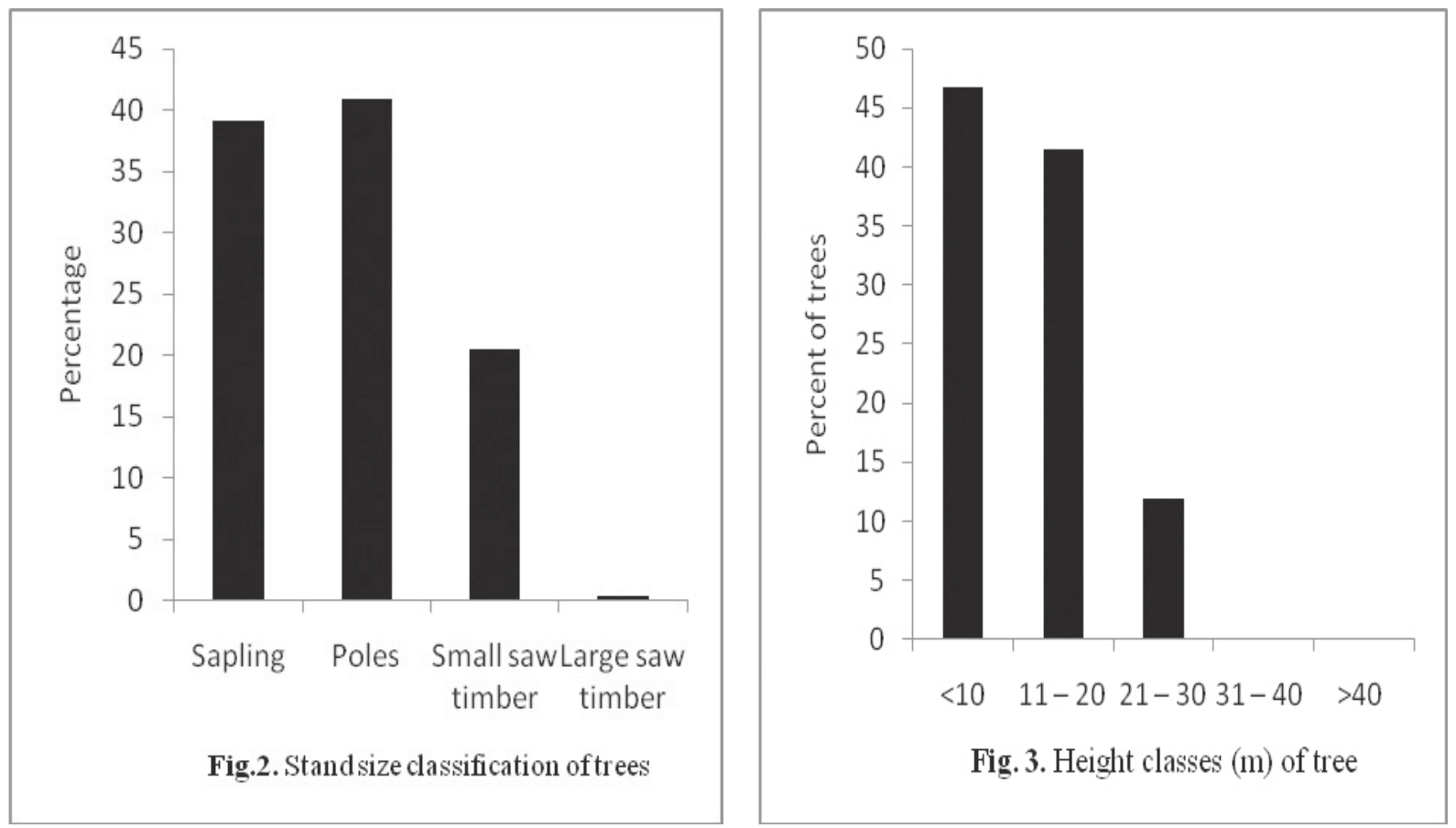
Table 2. Biomass of trees

\begin{tabular}{l|c|c|c|l|c}
\hline \multicolumn{1}{c|}{ Species } & $\begin{array}{c}\text { Total leaf } \\
\text { biomass (kg/ha) }\end{array}$ & $\begin{array}{c}\text { Total branch } \\
\text { biomass (kg/ha) }\end{array}$ & $\begin{array}{c}\text { Total stem } \\
\text { biomass (kg/ha) }\end{array}$ & $\begin{array}{l}\text { Total biomass } \\
\text { (kg/ha) }\end{array}$ & $\begin{array}{c}\text { Total } \\
\text { biomass (\%) }\end{array}$ \\
\hline Albizia julibrissin & 4.82 & 16.02 & - & 20.85 & 0.51 \\
Alnus nepalensis & 44.45 & 46.59 & 117.14 & 208.18 & 5.17 \\
Castanopsis indica & 251.3 & 483.7 & 1455.7 & 2190.7 & 54.47 \\
Choerospondias axillaris & 7.45 & 13.57 & 20.66 & 41.69 & 1.03 \\
Engelhardia spicata & 3.94 & 3.35 & 7.47 & 14.78 & 0.36 \\
Eurya accuminata & 7.32 & 9.94 & 49.43 & 66.70 & 1.65 \\
Ficus semicordata & 1.93 & 0.54 & 5.37 & 7.86 & 0.19 \\
Luculia grantissima & 4.06 & 7.40 & 11.27 & 22.75 & 0.56 \\
Lyonia ovalifolia & 1.73 & 13.82 & 6.18 & 21.73 & 0.54 \\
Maesa chisia & 21.93 & 39.97 & 60.84 & 122.75 & 3.05 \\
Myrica esculenta & 62.6 & 203.7 & 372.6 & 638.9 & 15.88 \\
Pinus roxburghii & 9.73 & 2.05 & 29.27 & 41.05 & 1.02 \\
Pinus wallichiana & 24.40 & 30.86 & 27.55 & 82.81 & 2.05 \\
Prunus cerasoides & 1.63 & 5.90 & 8.43 & 15.96 & 0.39 \\
Pyrus pashia & 0.85 & 3.10 & 4.43 & 8.38 & 0.20 \\
Rhododendron arboreum & 13.2 & 50 & 60.5 & 123.7 & 3.07 \\
Schima wallichii & 102.83 & 58.15 & 138.81 & 299.79 & 7.45 \\
Syzygium cumini & 16.57 & 30.20 & 45.97 & 92.75 & 2.30 \\
Total & 580.81 & 1018.93 & 2421.663 & 4021.416 & 100
\end{tabular}

\section{Species diversity and dominance}

The diversity of different forest components (trees, shrubs and herbs) was 2.33 for tree, 2.22 for shrubs and 2.17 for herbs (Table 3). An assessment of extent of dominance from the structural stand point has been made by computing the species importance value as an index. Only four species $A$. nepalensis, $P$. roxburghii, $S$. wallichii and $M$. esculenta comprised about $68.39 \%$ of the total importance value and the remaining percent were shared among 14 different species including dead trees. A. nepalensis constituted more than $26 \%$ of total importance value.

Table 3. Species diversity and dominance

\begin{tabular}{l|l|l|l|l}
\hline Index & Shannon-Index (H) & Evenness (E) & Heterogeneity & Dominance (Do) \\
\hline Tree & 2.3317043 & 0.806714 & 0.193285 & 0.133605 \\
Shrub & 2.2225691 & 0.801622 & 0.198378 & 0.148277 \\
Herb & 2.1788686 & 0.676904 & 0.323096 & 0.178218 \\
\hline
\end{tabular}

\section{Discussion}

The forest of the study area was mainly dominated by A. nepalensis, S. wallichii and P. roxburghii. However, Malla (2005) reported that $R$. arboreum as dominating species in Bishnubudanilkantha region and $C$. indica and Quercus semicarpifolia in Shivapuri Peak of Shivapuri National Park. It may be due to the different topography and edaphic factors (Krebs 1972). The value of total tree density was 840 stems/ha, which is similar to the finding of Kumpakha (2008) in the Sundarijal VDC of Shivapuri National Park. Generally the diversity of herb species is greater in rainy seasons and in summer low moisture content in the soil as well as the fire affect the diversity of herbs. The forest stands showed the high percent of poles (40.95\%) and sapling which is similar to the findings of Amatya (1993). This indicates that the forest has been intensively used long time for various forest products.

The importance value was 79.02 for A. nepalensis. Sigdel (2008) obtained only 21.16 importance value for this species in Bishnubudanilkantha region. The higher 
importance value in the present study compared to other species showed that these species are ecologically important to maintain the existing ecosystem. The average above ground biomass was $4021.41 \mathrm{~kg} / \mathrm{ha}$ in Sikre forest. C. indica (2190.7kg/ha) contributed the highest biomass. Based on potential resources supply and household demand of forest product from the community forest, the status of forest was found to be degraded and subjected to greater harvest. There was annual deficit of $112.038 \mathrm{t} / \mathrm{yr}$ of fuel wood at Sikre VDC. According to Pandey (1976 cited in Amatya 1993) 4216t ground grass (undergrowth) and $12,650 \mathrm{t}$ of tree leaves as fodder can be removed from the proposed BZ forest of ShNP whereas fuel wood consumption was estimated to be $18,750 \mathrm{t} / \mathrm{yr}$ which was higher than yield from the forest $(8,708 \mathrm{t} / \mathrm{yr})$. As there was a shortage of fuel wood and fodder, plantation of fuel wood and fodder species should be given priority in the buffer zone to meet the need.

The total density 184/ha of cut stumps and 216/ha of lopping was observed in study area of the forest. Kumpakha (2008) obtained higher total density of cut stumps (426.667/ha) and lopping (1134.67/ha) in Sundarijal VDC of ShNP which showed that the human disturbances were found to be much lower in the study area. S. wallichii (40/ha), M. chisia (28/ha) and A. nepalensis (24/ha) were the most common cut stump species among other species. Household's fodder and fuel wood need might have been fulfilled by this.

\section{Acknowledgements}

Dr. Dinesh Raj Bhuju provided invaluable suggestions to improve sampling strategy, data collection plan and analyze results, Ms. Asha Laxmi Suwal supported us in the field and analyzed the data. We are thankful to the Department of National Parks and Wildlife Conservation (DNPWC) and ShNP for providing permission to carry out this research. We are also thankful to all the members of CFUGs and local people who provided valuable information to us.

\section{References}

Amatya, D. 1993. Study on forest vegetation analysis. Shivapuri integrated watershed development project. GCP/NEP/048/NOR. HMG Nepal and FAO. 14 pp.

Brown, S., A.J.R. Gillespie and A.E. Lugo. 1989. Biomass estimation methods for tropical forests with applications to forest inventory data. Forest Science 35:881-902.

Chaudhary, R.P. and R.M. Kunwar. 2002. Vegetation composition of Arun Valley, Eastern Nepal. In: Vegetation and society: Their interaction in the Himalayas. Kathmandu, Tribhuvan University Kathmandu and University of Bergen Norway, Pp. 38-55.

Geldenhuys, C.J. and B. Murray. 1993. Floristic and structural composition of Hanglip forest in the Southpansberg, Northern Transvaal. South African Journal 165:9-20.

Kapur, P. and S.R. Govil. 2000. Experimental plant ecology. CBS Publishers and Distributors, Dariyaganj, New Delhi, India.

Karki, M.B. 1991. The rehabilitation of forestland in Nepal. Nature Resource 27(4):38-46.

Khanal, A. 2007. Estimating the potential of community carbon forest - A case from Champadevi community forest. M.Sc. dissertation. Central Department of Environmental Science, Tribhuvan University, Kirtipur, Nepal.

Krebs, C.J. 1972. Ecology: The experimental analysis of distribution and abundance. Harper and Row, New York. 694 pp.

Kumpakha, B. 2008. Resource use, livelihood and biodiversity conservation in Shivapuri national park - A case of Sundarijal VDC. M.Sc. dissertation. Department of Environmental Science, Khwopa College, Bhaktapur, Kathmandu, Nepal.

Longman, K.A. and J. Jenik. 1987. Tropical forests and its environment. Longman Publishers, Singapur. 347 pp.

Malla, B.B. 2005. Environmental study on soil loss of upper Bishnumati watershed in Shivapuri national park. M.Sc. dissertation. Central Department of Environmental Science, Tribhuvan University, Kritipur, Kathmandu, Nepal.

NARMSAP and DoF. 2000. Biomass and volumes tables with species description for community forest management. TISC Paper Series NO. 101, Final Report, Ministry of Forest and Soil Conservation, Kathmandu, Nepal. 90 pp.

Ojha, H. and B. Pokharel. 2005. Democratic innovations in community forestry - What can politicians learn? Participation 7:22-25.

Shannon, C.E. and W. Weaver. 1949. The mathematical theory of communication. Urbana III. Univ. Illinois Press, USA.

Shrestha, K. 1998. Dictionary of Nepalese plant names. Mandala Book Point, Kantipath, Kathmandu, Nepal.

Sigdel, S.R. 2008. Attitudinally coordinated pattern of plant community structure in the Shivapuri national park, Nepal. Banko Jankari 18:11-17.

Stainton, J.D.A. 1988. Flowers of the Himalaya. Oxford Press, New Delhi, India. 